\title{
FORM OF COMMODIFICATION OF DECORATIVE VARIETY OF GAYO SKIN MOTIF IN KEBAYAKAN DISTRICT, ACEH CENTRAL REGENCY
}

\author{
Rita Fitri ${ }^{1}$, Ibnu Hajar ${ }^{2}$, Nurjannah ${ }^{3}$ \\ Universitas Negeri Medan \\ ritafitri1994@gmail.com
}

\begin{abstract}
The study is intended to determine how the form of commodification variety of Kerawang Gayo decorative motifs in the Kebayakan District of Central Aceh Regency. This research is carried out through research qualitative with descriptive approach. The informant of the research is determined by purposive sampling technique to involve leaders of indigenous, artisans of Kerawang Gayo and designers. Data collection techniques were carried out through in-depth interviews, participatory observation and documentation. The result of the research shows that commodification is a process that is not only related to how products are becoming the product of mass, but it also relates to how a product that can be distributed to the market to meet the needs of consumers. The form of commodification variety of decorative motifs filigree Gayo is not only poured on the walls of the house indigenous Gayo, but it has been modified in some form of products such as upuh ulen-ulen, fashion custom wedding, bags, caps and other souvenirs. The motifs that are used in the form of commodification filigree Gayo consist of five motif bases that is emun berangkat, pucuk rebung, puter tali, tapak seleman, dan peger. Thus, the commodification is becoming very important in preserving the art of culture, both for the benefit of sustainability as well as the increase in business that motif used still maintained its continuity and become the identity of the tribe Gayo that in the call with Kerawang Gayo.
\end{abstract}

Key words : form of commodification, motif, Kerawang Gayo

\section{INTRODUCTION}

Commodification is a process where more and more human activities have monetary value and become goods that are sold in the market (Abercrombie et al ., 2010: 94). K omodifikasi make something ya ng is not a commodity and then Seol ah if a commodity that can be treated just like a commodity that can be traded for profit. Commodities can be defined as the results of human labor, whether in the form of goods or services, which are deliberately produced to be exchanged through market mechanisms. Commodities as goods and services are generally mass produced, serve the needs of many consumers and are also reproduced repeatedly to meet the needs of the consumer community who are the target market. Commodities represent the symbolic and material forms used to reproduce labor through consumption ( Lee, 2006: 2004).

The important aspect in commodities is that commodities must have a use value, in the sense that the goods and services are useful to satisfy certain needs. In addition, a commodity must be able to be exchanged for other goods or services that are different in use or known as exchange rates. A commodity therein also bears a price on the good itself. Prices are a reflection of the exchange rate or the value of a commodity. Because goods will not be purchased by consumers if they do not offer use value or benefits that can be felt by society. In the Gayo community, goods that have a useful value are kerawang Gayo. According to Iwan Gayo (Zainal. 2002: 18) kerawang Gayo is the name of an ornamental motif which initially only existed on the walls of traditional traditional houses to beautify the building of traditional houses of the Gayo tribe. The motives 
used are emun berangkat, pucuk rebung, puter tali, tapak seleman dan peger. This motif has its own meaning and meaning that comes from the reflection of traditional leaders to serve as the basis of life for the Gayo community, so that it becomes a symbol or identity of the Gayo tribe.

The development of the times, the more developing the creativity of the Gayo community, kerawang Gayo is not only used as a wall decoration for traditional houses but is modified in the form of products so that they can be exchanged for the market for profit. This is inseparable from the role of craftsmen and designers in modifying kerawang Gayo forms for business purposes and maintaining the continuity of decoration as a cultural heritage of the Gayo community. Therefore, in this process of commodification, something is produced not primarily on the basis of use value, but rather on exchange value. This means that something is produced not merely to have a use for the audience, but more because something can be exchanged in the market. Thus the production orientation is not intended to meet the objective needs of society but rather encourages capital accumulation.

Based on the above review, the theory that supports this study is the theory of consumption from Jean Baudrillard. According to Baudrillard, the main function of objects of consumption is not their use or benefits, but rather a function as sign values or symbol values that are disseminated through style advertisements. life of various media (Baudrillard, 1969: 19). The needs of a person are more and more diverse, so society must follow that diversity and its replacement. According to Baudrillard, society must follow the rhythm of necessities and their replacement continuously (Baudrillard, 1970: 18). Then the relationship between the consumer and the object of consumption changes. Consumers no longer buy goods because of the benefits contained therein, but because they are related to the overall meaning of the object.

\section{METHOD}

The type of research used is qualitative with a descriptive approach (Moleong , 2005 ). The informants in this study were determined based on purposive sampling technique based on their ability to provide information to answer the problem formulation in this study. There are 4 informants in this study consisting of 1 person as a traditional leader who explains the meaning and function of gayo openwork for the gayo community. while 1 person is an iner village who designs motifs and shapes in the commodification process. Furthermore, 2 Gayo Kerawang craftsmen, who carry out the creativity of the process of commodifying the Gayo openwork motif and collaborating with the designers so that the form of the Gayo filigree commodification can attract tourists for profit . This research was conducted at Eweh Tami Delem Hill, Kebayakan Subdistrict, Central Aceh Regency. Data collection techniques are carried out through in-depth interviews, observation and documentation study. Meanwhile, data analysis is done by reducing data, data categories, synthesizing and formulating certain statements (Bungin, 2003).

\section{FINDINGS AND DISCUSSION}

\section{The form of Commodification of Kerawang Gayo}

Commodification is a process that makes something that was not previously a commodity so that it becomes a commodity of Piliang (2003: 86). The purpose of Piliang's opinion on commodification is that commodification does not only refer to consumer goods, but rather refers to art forms and culture in general. Commodity and commodification are two things that have a relationship between object and process. Commodities are understood as something that is produced for sale. Soedarsono (1995) ( in Briyan Titus 2017: 18) said that sooner or later, culture will always change. The transformation can be related to its shape, but also to its value. This form of commodification of Gayo openwork is studied in terms of cultural studies through analysis which explains the commodification of production, artistic value, cultural value and distribution. 


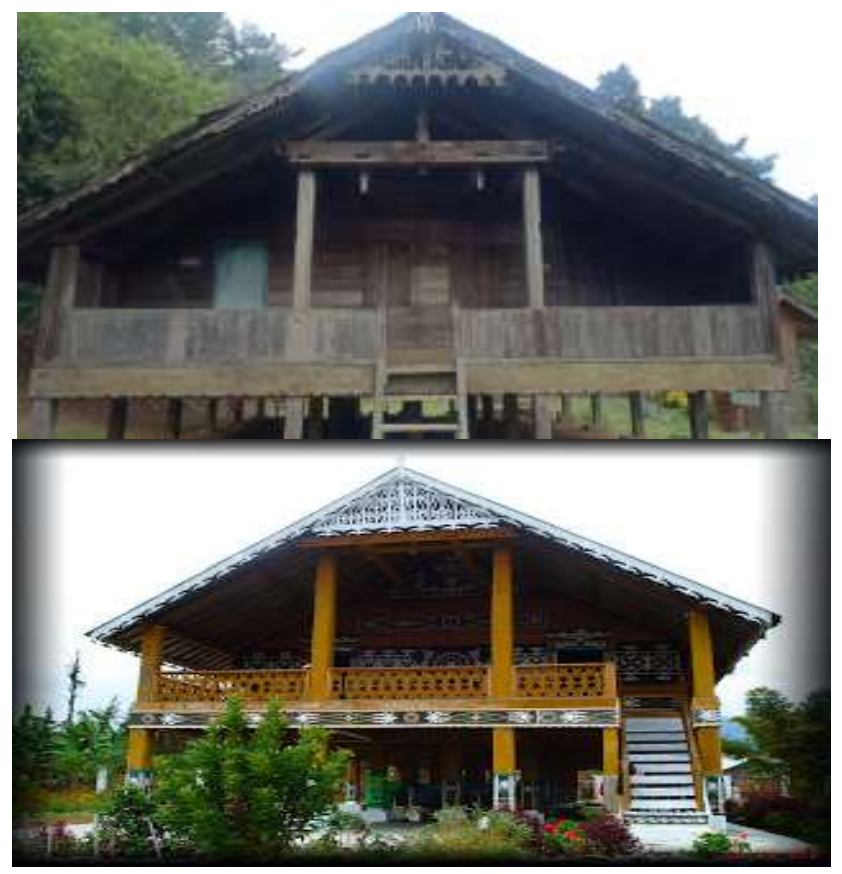

(Source: Researchers Documentation 2020)

And then with the technological development of society creativity lies not only limited to carving on the houses of indigenous Gayo, but have switched to fashion goods, which continues to follow the market needs to improve the community's economy. This is a great opportunity for the craftsmen in the area to improve their lives.

Cultural commodification occurs in the Gayo filigree production process . According to Mosco (2009) (in Briyan Titus. 2017: 8) the embroidery process is now made with an industrial system. Motivation of actors in embroidery who are increasingly business oriented. Commodification can be seen here, namely changing the value of a product that previously only had a use value then into an exchange rate or selling value, where the value of the need for this product is determined by the price that has been designed by the producer. Commodification is the process of modifying a traditional kerawang Gayo product by changing its size, shape (traditional to modern), and simplification, according to consumer demand and market demands.

When connected with culture, commodification is an effort to make everything culture profitable. Commodification of value (content) explains how the cultural value produced becomes the commodity that is offered. This commodification process produces various forms of new products that are different from the original form. The process of changing forms arises from the innovation and creativity of designers, consumers, and the industry itself. As a work of art that has economic value, the change in form must have a value that can be sold or traded, this value is an artistic value and a cultural value. Artistic value (artistic value) is a value that can manifest an art or skill to do a job and cultural values (cultural value) is a value that can provide or contain a deep relationship with a society, civilization or culture. When examined from the value of fine art, Gayo's filigree is an embroidery work that has cultural and artistic values. The artistic value of the Gayo openwork is an art object that can be seen and commodified in terms of modification, physical form, motifs, colors and merging with other elements. 
Figure 2. Commodified form of kerawang Gayo

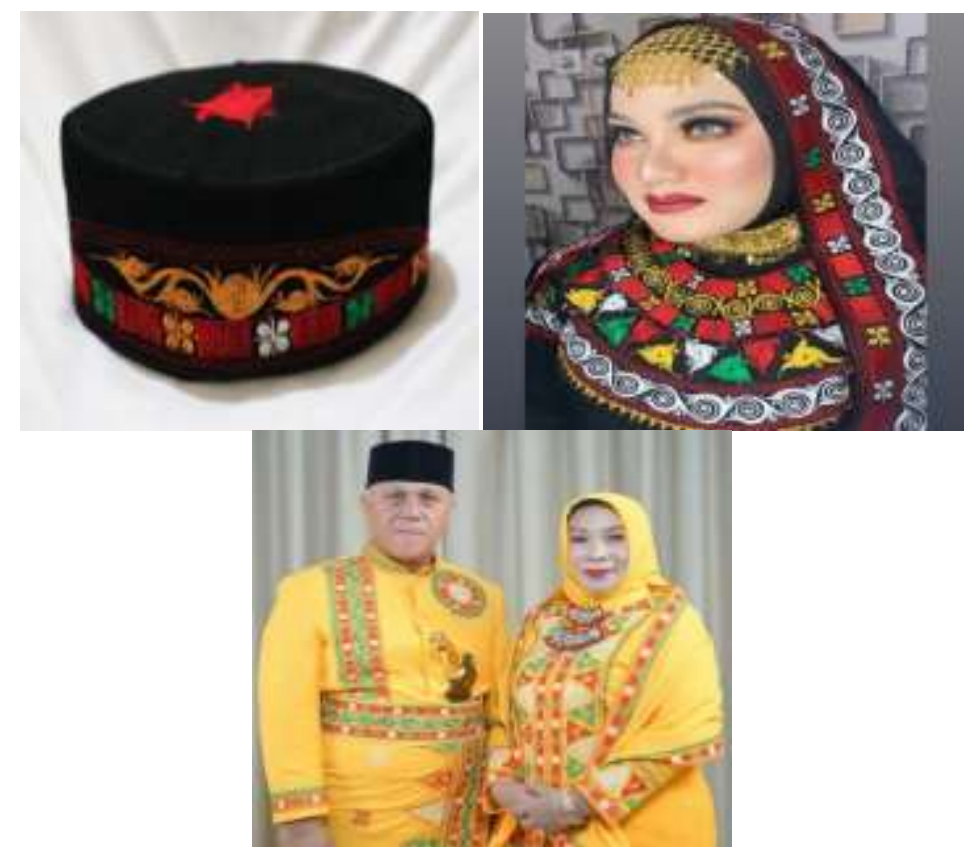

Source (Researchers Documentation 2020)

The extreme modification of the Gayo openwork is also carried out by creative communities such as craftsmen and designers who have now turned it into wearables such as traditional bridal clothing, scarves, women's dresses, curtains, bed covers, tablecloths, masks, sarongs, wall hangings, various bags, wallets, hats, and various other fashion souvenirs. Although most of the gayo filigree has been modified, the Gayo filigree is still a work of embroidering motifs that have cultural values. The cultural values of the Gayo filigree are customary values that serve as role models in guiding the Gayo community in its production and use. Each type of Gayo openwork has its own cultural values that have been determined by the ancestors of the previous community based on the concept of space and time as local wisdom of the Gayo community.

\section{Figure 3. Traditional bridal clothing and Gayo openwork Kerawang Gayo}

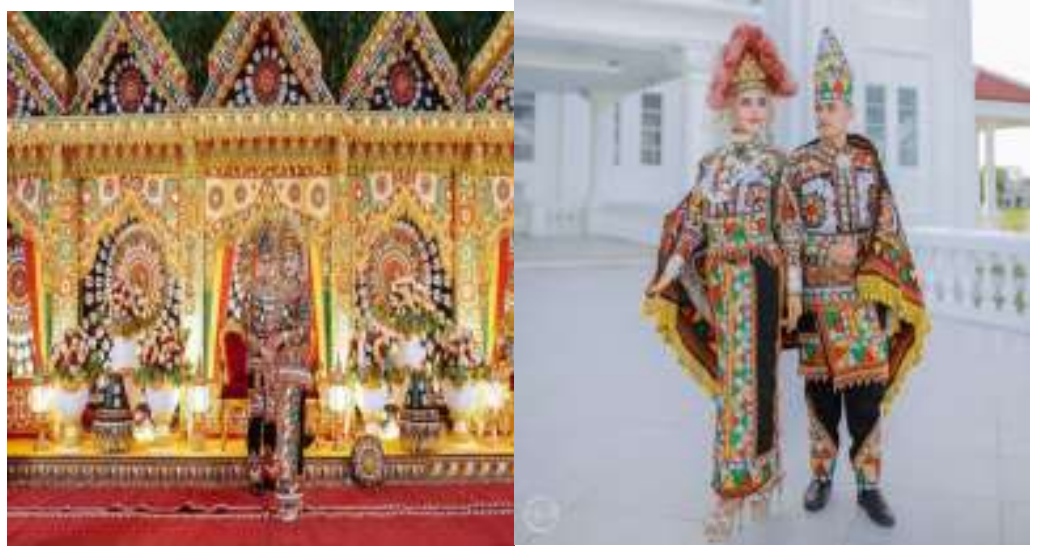

(Source : Researchers Documentation 2020)

Copyright C2021 JOEPALLT

Journal of English Pedagogy, Linguistics, Literature, and Teaching 
Based on the picture above, it shows the traditional traditional clothing of the Gayo tribe, where the wedding is equipped with a carving of the Gayo openwork motif which is only found in the Gayo tribe area. The values contained therein have their own meaning, starting from the learning program (asking for the blessing of both parents), by using a blanket upuh ulen-ulen (moon cloth) which has a meaning as a symbol of strength and sheds light on the world. And usually the use of upuh ulen-ulen is only done at certain events because it has sacred properties such as holding a wedding ceremony, welcoming the president / minister or other artistic events.

Table 1. sales price of kerawang Gayo

\begin{tabular}{|l|l|l|l|l|}
\hline No. & Product name & Price & Buyer & consumer \\
\hline 1 & upuh ulen-ulen & $\begin{array}{l}1,000,000 .- \\
2,000,000\end{array}$ & $\begin{array}{l}\text { traditional leaders, } \\
\text { owners of the aisle } \\
\text { equipment and } \\
\text { officials }\end{array}$ & $\begin{array}{l}\text { officials, the bride and groom } \\
\text { and the elephant }\end{array}$ \\
\hline 2 & shawl & 600,000 & official mothers & $\begin{array}{l}\text { mothers while on certain } \\
\text { occasions. }\end{array}$ \\
\hline 3 & robe suit & 400,000 & $\begin{array}{l}\text { among women, } \\
\text { especially teachers } \\
\text { and officials }\end{array}$ & $\begin{array}{l}\text { all groups, including officials, } \\
\text { housewives, civil servant } \\
\text { teachers, and teenagers }\end{array}$ \\
\hline 4 & bag & $\begin{array}{l}\text { schoolchildren, } \\
\text { college students, } \\
\text { teachers, and official } \\
\text { mothers }\end{array}$ & $\begin{array}{l}\text { schoolchildren, } \\
\text { students, teachers, and } \\
\text { official mothers }\end{array}$ \\
\hline 5 & cap & $\begin{array}{l}\text { among men } \\
80,000-\end{array}$ & $\begin{array}{l}\text { all circles of children, } \\
\text { teenagers and tourists }\end{array}$ & $\begin{array}{l}\text { all circles of children, } \\
\text { teenagers and tourists }\end{array}$ \\
\hline 6 & $\begin{array}{l}\text { bracelets, } \\
\text { wallets and } \\
\text { masks }\end{array}$ & $\begin{array}{l}10,000- \\
35,000\end{array}$ &
\end{tabular}

Based on the contents of the table above, it can be seen that the various kinds of products needed by people and consumers are different, because many buyers see the price list first before buying the product they want. Therefore different products are also different for buyers, as in point one, these ulen-ulen are only bought by upper class people, such as traditional leaders, this cloth is bought to meet the needs of the community, for example in conducting a wedding ceremony you must use the moon cloth so you don't borrowed or leased again from someone else. Except that reason, upuh ulen-ulen is a symbol of honor for the people of Gayo itself therefore any officials such as the president and his ministers more warmly greeted with upuh-ulen-ulen with how draped dibadan the guest of honor as the identity of Gayo .

The product that consumers are most interested in from time to time depends on the buyer, if the buyer is from the upper class, then the best-selling product in the market is upuh ulenulen, scarves and skirts to complement women's clothing. Because these products have a fairly high price compared to caps, bags and other souvenirs that are easily accessible by the middle class. For example, a craftsman who already has a large and well-known shop in the market has a monthly income of IDR 15,000,000-20,000,000. Another case with home craftsmen who have a weekly income ranging from Rp. 500,000-1,000,000. Since the pandemic hit the world, not a few craftsmen have experienced a decrease in income in carrying out their daily routine. Except for getting orders to make masks with the Gayo openwork motif. case in accordance with the information that researchers can from the field during an interview with one of the craftsmen Mother Chintya on September 24, 2020 as the following:

".... As for the income this year, you could say that it has decreased significantly compared to the previous years. Because seen from the covid situation, which until now hasn't stopped, you want a year too, right ? Usually, visitors are always busy, especially when the coffee harvest is in the same season, the income is quite large, around Rp. 
$15,000,000$ to Rp. $35,000,000$ per month. Yes, now it is at most Rp. 3,000,000 to Rp. $6,000,000$ because of the pandemic , the lockdown occurred, the price of coffee dropped again drastically, even for the palawija plants there was no price anymore right ? ... "

The above expression is clear that profits have decreased drastically. Sales, which should have increased with the commodification of the resulting product, decreased in the amount of revenue. This is one of Chintya's worries during this pandemic.

\section{CONCLUSION}

Commodification is a process that is not only related to how production becomes a mass product, but also how the product can be distributed to the market to meet consumer needs. Commodification is related to the process of transforming goods and services from their use values into commodities that are oriented towards their exchange rates in the market. Commodification has been carried out into various types, forms and variations which become commodity goods that are ready to be produced by the market at attractive prices. Each product produced has its own meaning and function for its users. Like the moon cloth, which is a symbol of Gayo ethnic identity with its sacred use and is only used during certain events, such as wedding ceremonies and welcoming guests, which are a symbol of honor. Another form of the process of commodification of kerawang Gayo's motifs in the form of a robe suit, bag and scarf. This product is usually used by female officials, teachers and midwives with a modified Gayo openwork motif. Meanwhile, the kerawang Gayo shawl is only used at certain events such as weddings and other formal events. This product is in great demand by consumers so that it becomes an attraction for visiting tourists, both local and non-local tourists. So that goods that have become commodities are ready to be distributed to the market. This provides many advantages for the kerawang Gayo producers.

\section{REFERENCES}

Abidin, Zainal. 2002. Makna Simbolik Warna dan Motif Kerawang Gayo pada Pakaian Adat Masyarakat Gayo. Yogyakarta: Fakultas Bahasa dan Seni Universitas Negeri Yogyakarta.

Bungin, Burhan. (2003). Analisis Data Penelitian Kualitatif Pemahaman Filosofis dan Metodologis ke Arah Penguasaan Model Aplikasi. Jakarta : PT. Raja Grafindo Persada.

Haryatmoko. 2016. "Membongkar Rezim Kepastian Pemikiran Kritis Post Strukturalis". Yogyakarta: PT Kanisius

Moleng, Lexy. (2005). Metodologi Penelitian Kualitatif. Bandung : PT. Remaja Rosdakarya.

Titus, Briyan, Tarigan. 2017. “ Komodifikasi Kain Tradisional Karo Pada Era Globalisasi”. Jurnal Ilmiah Ilmu-ilmu Seni. Program Studi Magister Penciptaan dan Pengkajian Seni. Fakultas Ilmu Budaya Sumatera Utara.

Piliang, Yasraf Amir. 2003. Hipersemiotika, Tafsir Cultural Studies Atas Matinya Makna. Yogyakarta: Jalasutra. 